\title{
Seasonal Variations and Long-term Trend of Mineral Dust Aerosols over the Taiwan Region
}

Aerosol and Air Quality Research

\author{
Yanda Zhang ${ }^{1 *}$, Yi-Jhen $\mathrm{Cai}^{2}$, Fangqun $\mathrm{Yu}^{1{ }^{*}}$, Gan Luo ${ }^{1}$, Charles C.K. Chou ${ }^{3}$ \\ ${ }^{1}$ Atmospheric Sciences Research Center, State University of New York at Albany, Albany, New \\ York, USA \\ ${ }^{2}$ Department of Atmospheric Sciences, National Central University, Taoyuan, Taiwan \\ ${ }^{3}$ Research Center for Environmental Changes, Academia Sinica, Taipei, Taiwan
}

\section{OPEN ACCESS}

Received: July 22, 2020

Revised: November 23, 2020

Accepted: November 24, 2020

${ }^{*}$ Corresponding Authors:

Yanda Zhang

yzhang31@albany.edu

Fangqun $\mathrm{Yu}$

fyu@albany.edu

\section{Publisher:}

Taiwan Association for Aerosol Research

ISSN: $1680-8584$ print

ISSN: 2071-1409 online

(c) Copyright: The Author(s).

This is an open access article distributed under the terms of the Creative Commons Attribution License (CC BY 4.0), which permits unrestricted use, distribution, and reproduction in any medium, provided the original author and source are cited.

\section{ABSTRACT}

Atmospheric dust aerosols are known to affect the air quality and public health as well as climate and weather systems. An increasing number of modeling studies have related ice nucleation with the number concentrations of dust particles with a diameter larger than $500 \mathrm{~nm}\left(N_{D, d}>500 \mathrm{~nm}\right)$. In this paper, the seasonal variation, vertical properties, and long-term trend of $N_{D, d}>500 \mathrm{~nm}$ over the Taiwan region are analyzed, using simulations from a global chemical transport model with size-resolved particle microphysics. Over Taiwan, $N_{D, d}>500 \mathrm{~nm}$ shows a bimodal seasonal variation distribution with two peaks in spring (March-May) and fall-early winter (October-December). In the different seasons, $N_{D, d}>500 \mathrm{~nm}$ varies by about one order of magnitude from summer to spring $\left(0.06-1.23 \mathrm{~cm}^{-3}\right.$ in the boundary layer, $0.03-0.55 \mathrm{~cm}^{-3}$ in the middle and lower troposphere, and $0.006-0.03 \mathrm{~cm}^{-3}$ in the upper level). Vertically, $N_{D, d}>500 \mathrm{~nm}$ profiles show the unimodal distribution, with the highest $N_{D, d}>500 \mathrm{~nm}$ appears at $\sim 1 \mathrm{~km}$ and decreasing with altitude. From surface to high levels, the frequencies of intense dust events decrease in fall (September-November) and increase in summer months (June-August). The long-term model results suggest a decreasing trend of the strong dust event frequencies and annual mean $N_{D, d>500 \mathrm{~nm}}$ over Taiwan in the last two decades. From 1999 to 2018, the number of strong dust event days and $N_{D, d}>500 \mathrm{~nm}$ decreased by $40-43 \%$ and $37-54 \%$, respectively, under $4 \mathrm{~km}$, and the decline is weaker at higher altitudes. The analysis suggests that these decrease trends are caused by the declining Asian dust emissions.

Keywords: Mineral dust number concentration, Ice nuclei, Dust aerosols in Taiwan, Long-term trend of dust

\section{INTRODUCTION}

Mineral dust is indicated to make a significant contribution to global atmospheric aerosol loading, for its large emission rate (up to $5000 \mathrm{Tg} \mathrm{yr}^{-1}$ ) (Engelstaedter et al., 2006) and long-range transportability (Huang et al., 2008; Uno et al., 2009). Dust storms are observed to influence air quality and public health worldwide (Ganor et al., 2009). Mineral dust particles have significant impacts on climate and weather systems by altering the radiation forcing (Tegen et al., 1997; Liao and Seinfeld, 1998), cloud nucleation (Levin et al., 1996; DeMott et al., 2003), and convective invigoration (Andreae et al., 2004). The indirect influences of dust on clouds have also been revealed by a series of observations and numerical studies (Tao et al., 2012; Liu et al., 2012a, b; Fan et al., 2016; Kanji et al., 2017). Dust particles are recognized as one of the most important ice-nucleating particles (INPs), by influencing the heterogeneous freezing in the mixed-phase clouds ( $>-37^{\circ} \mathrm{C}$ ) (Hoose and Möhler, 2012; Murray et al., 2012). Previous observation studies reveal that the long-range transported dust particles play a critical role in the development of cloud and precipitation (Ault et al., 2011; Creamean et al., 2013). Modeling studies indicate that the presence of mineral dust leads to the initiation of mixed-phase clouds and increases precipitation efficiency (Muhlbauer and Lohmann, 2009; Fan et al., 2014). Our recent study based on a long-term 
analysis of multiple datasets suggests a significant correlation between atmospheric dust loading and the summertime precipitation over the mountainous region in Taiwan (Zhang et al., 2020). Thus, an increasing number of numerical models have explicitly considered the dependence of ice nucleation rate on dust number concentrations (DeMott et al., 2010; Thompson and Eidhammer, 2013; DeMott et al., 2015).

Over the Taiwan region, dust storms are indicated by numerous studies to have significant impacts on air quality, visibility, and public health over the Taiwan area (Chen et al., 2005; Cheng et al., 2005; Liu et al., 2006; Chiu et al., 2008). Located in East Asia, Taiwan is highly influenced by the long-range transport of mineral dust aerosols from mainland China, the Middle East, and the Sahara (Chen et al., 2004; Lin et al., 2007; Liu et al., 2009; Chang et al., 2010; Lin et al., 2012; Shahsavani et al., 2012; Hsu et al., 2012). Recent research also suggests the wintertime river-dust as a local source of dust aerosols (Lin et al., 2018). Series of studies on atmospheric dust aerosols have been conducted in Taiwan, providing a profound understanding of mineral dust properties over this region (Liu and Shiu, 2001; Hsu et al., 2008; Lin et al., 2012; Tsai et al., 2014; Provençal et al., 2017). However, restricted by the observation technology, there are few studies on the long-term 3-dimensional dust properties in the area.

In this context, we use a global chemical transport model with size-resolved particle microphysics to study the mineral dust aerosols over the Taiwan region from 1999 to 2018. The main objective of the present work is to study the temporal and spatial characteristics of dust aerosols, including the typical value of dust number concentrations, seasonal variation, vertical distribution, and the long-term trends, that could provide a profound understanding of mineral dust aerosols and help to improve the dust-ice nucleation parameterizations over Taiwan.

\section{MODEL DESCRIPTION AND VALIDATION}

\subsection{Model and Data}

(1) GEOS-Chem-APM model and dust simulations: Limited by the lack of long-term 3-D quantitative observations, dust mass, and number concentration simulations are used in our research. The dust simulation is based on a global 3-D chemical transport model (GEOS-Chem) with size-resolved Advanced Particle Microphysics (APM) model incorporated (Yu and Luo, 2009). GEOS-Chem-APM model is driven by Global Modeling and Assimilation Office (GMAO) ModernEra Retrospective analysis for Research and Applications, Version 2 (MERRA-2) meteorology fields. The GEOS-Chem-APM model was run globally at $2^{\circ} \times 2.5^{\circ}$ horizontal resolution and 47 vertical layers (with 14 layers from the surface to $\sim 2 \mathrm{~km}$ ), from 1999 to 2018. In the GEOS-Chem-APM, dust emission is calculated with the Mineral Dust Entrainment and Deposition (DEAD) scheme (Zender et al., 2003), and dust aerosols with diameters from $30 \mathrm{~nm}$ to $25 \mu \mathrm{m}$ are represented by 15 bins. In previous studies, GEOS-Chem has been widely validated and used for dust simulations (Prenni et al., 2009; Xu et al., 2017; Zhang et al., 2019). Hourly Dust simulations by GEOS-ChemAPM are outputted at two grids of LLN (Lulin) site $\left(23.47^{\circ} \mathrm{N}, 120^{\circ} \mathrm{E}\right)$ and TP (Taipei) site $\left(25.09^{\circ} \mathrm{N}\right.$, $121.56^{\circ} \mathrm{E}$ ) over the Taiwan region. Previous measurements indicate that the heterogeneous freezing of cloud ice particles is closely related to the dust number concentration with a diameter larger than $500 \mathrm{~nm}\left(N_{D, d}>500 \mathrm{~nm}\right)$ (DeMott et al., 2010; Creamean et al., 2013). Thus $N_{D, d}>500 \mathrm{~nm}$ (procced into local time) is used to represent the strength of daily dust aerosol loading at each level over Taiwan. Mass concentration of dust smaller than $10 \mu \mathrm{m}\left(\mathrm{PM}_{10}\right)$ is also output to compare to the observations to validate the model simulation.

(2) CALIPSO dust observation: Cloud-Aerosol Lidar and Infrared Pathfinder Satellite Observations (CALIPSO) Lidar Level 2 Vertical Feature Mask Data (https://www-calipso.larc.nasa.gov) provided by the NASA Langley Research Center's (LaRC) ASDC DAAC and NASA Earth Science Data and Information System (ESDIS) project are used in this study (Winker, 2018). CALIPSO observations from 2006 to 2018 with satellite track passing through Taiwan $\left(21.7^{\circ}-25.5^{\circ} \mathrm{N}, 119.8^{\circ}-122.2^{\circ} \mathrm{E}\right)$ are used to represent the atmospheric dust loading in this area. CALIPSO level 2 classified aerosol data provides information on the vertical properties of dust, polluted dust, biomass burning, polluted continental, clean continental, and clean marine aerosols. In this study, the classified "dust" and "polluted dust" pixels are treated as dust signals. As there is no quantitative dust concentration in the CALIPSO data, the dust ratio is used as the qualitative reference, which is 
defined as the ratios of dust pixels to all pixels within $23^{\circ}-25^{\circ} \mathrm{N}$ under $10 \mathrm{~km}$. Dust ratios are used to compare with and validate the GEOS-Chem $N_{D, d}>500 \mathrm{~nm}$ simulations. The CALIPSO observations with more than $20 \%$ missing data in this region are excluded.

(3) $\mathrm{PM}_{10}$. Aerosol Speciation: Long-term in-situ aerosol sampling (2006-2017) was conducted at the Cape Fuguei Research Station $\left(25.30^{\circ} \mathrm{N}, 121.54^{\circ} \mathrm{E}, 10 \mathrm{~m}\right)$ at the northern tip of Taiwan Island (Chou et al., 2017). Mass concentrations of $\mathrm{PM}_{10}$ aerosols, organic carbon (OC), elemental carbon (EC), $\mathrm{Na}^{+}, \mathrm{NH}_{4}^{+}, \mathrm{K}^{+}, \mathrm{Mg}^{2+}, \mathrm{Ca}^{2+}, \mathrm{Cl}^{-}, \mathrm{NO}_{3}{ }^{-}, \mathrm{SO}_{4}{ }^{2-}$ were observed at this station. As there is no direct observation of mineral dust, Calcium ion concentration is used as a proxy. Ca is considered as one of the basic elements composing mineral dust (Perry et al., 1997; Formenti et al., 2008; Remoundaki et al., 2011), by following the method of Song and Carmichael (2001), we assume a calcium/dust ratio of $6.8 \%$ to estimate the mass loading of dust particles (Song and Carmichael, 2001). The derived $\mathrm{PM}_{10}$ dust mass concentrations are compared with the $\mathrm{PM}_{10}$ dust concentrations simulated by the GEOS-Chem-APM model at the surface level in the same region.

\subsection{Validation of Model Dust Simulations}

Fig. 1(a) shows the CALIPSO satellite tracks passing the Taiwan region. Examples of one strong dust event on May 02, 2010 (Fig. 1(b)) and one clean case on June 19, 2010 (Fig. 1(c)) show the
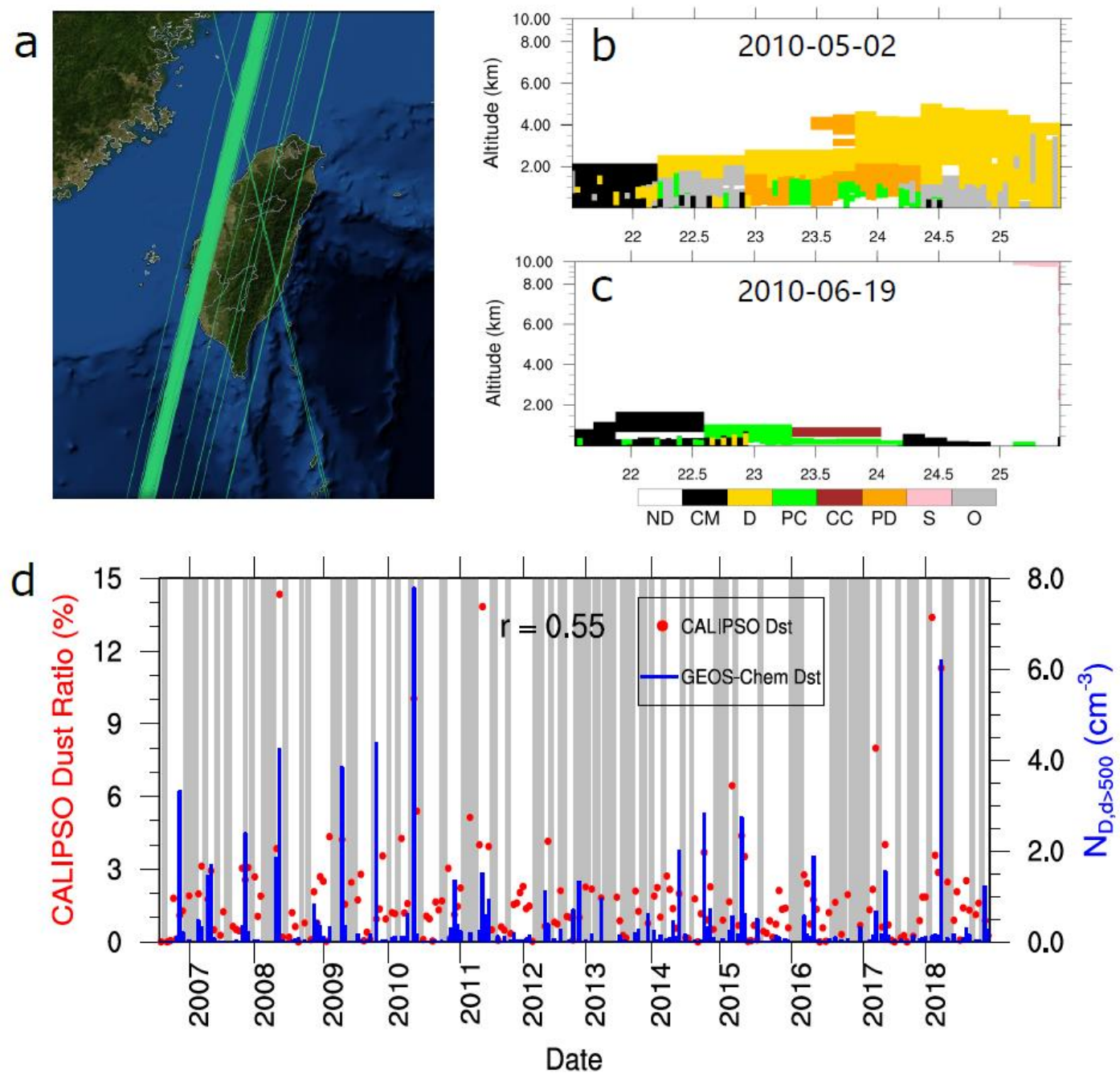

Fig. 1. (a) Satellite tracks (red line) of the 187 selected CALIPSO observations; Examples of (b) dusty and (c) clean days observed by the CALIPSO satellite (ND = "not determined", CM = "clean marine", D = "Dust", PC = "Polluted continental", CC = "clean continental", PD = "Polluted dust", $S=$ "smoke" $\mathrm{O}=$ "other"); and (d) CALIPSO observed dust pixel ratios (red spots) and model $N_{D, d}>500 \mathrm{~nm}$ simulations (blue columns) in the selected days, and grey shades are those days CALIPSO has over $20 \%$ missing data (not used in the comparison). 
obvious difference, indicating that CALISPO observations can capture the dust signals be used to identify the occurrence of dust events. Fig. 1(d) shows the comparisons between CALIPSO dust ratios and GEOS-Chem $N_{D, d>500 \mathrm{~nm}}$ simulations for all 187 days. The result suggests that $N_{D, d>500 \mathrm{~nm}}$ simulations are generally consistent with the CALIPSO observations $(r=0.55)$ and the GEOS-Chem model can simulate the temporal variation of atmospheric dust loading and observed strong dust events over the Taiwan area. However, as the quantitative dust concentration is not available in the CALIPSO dataset, dust ratios may not be proportional to the dust number concentration. In Table 1, 26 strong dust events observed by CALIPSO (with dust ratio > 10\%) are selected to qualitatively compare with the GEOS-Chem dust simulations on the corresponding date. The result shows that, in the 26 days with CALIPSO dust signals, GEOS-Chem simulated 25 dust events (top $25 \%, N_{D, d}>500 \mathrm{~nm}>0.1 \mathrm{~cm}^{-3}$ ) $(96 \%)$ and 21 strong dust events (top $10 \%, N_{D, d}>500 \mathrm{~nm}>0.2 \mathrm{~cm}^{-3}$ ) $(81 \%)$. The result suggests that the GEOS-Chem model can simulate most of the intermittent strong dust events, which is one of the major sources of atmospheric dust over the Taiwan region (Chen et al., 2004; Hsu et al., 2012; Lin et al., 2012; Chou et al., 2017).

To validate the long-term GEOS-Chem-APM dust simulation, we compare the surface PM $_{10}$ dust mass concentration simulations with the in-situ dust observations. To filter out some background noises, observation samplings with the lower $20 \%$ values are eliminated, by following the approach of Hand et al. (2016) and Achakulwisut et al. (2017). Fig. 2 shows the comparison between the time series of the observed and simulated dust mass concentrations that the temporal variation of model dust simulation generally matches with the observation, and the model result can simulate the observed strong dust events. In the 1928 observation days (20032017), the model dust simulation shows a high correlation with the observation $(r=0.69)$. The mean model dust concentration is $8.73 \mu \mathrm{g} \mathrm{m}^{-3}$, close to the mean value of dust observation $\left(7.32 \mu \mathrm{g} \mathrm{m}^{-3}\right)$. Fig. 2 also reveals that, to some extent, the GEOS-Chem model underestimated the dust concentration during weak dust days and overestimated the strong dust events. This

Table 1. Dates, CALIPSO dust ratios (\%), and GEOS-Chem $\mathrm{N}_{\mathrm{D}, \mathrm{d}>500 \mathrm{~nm}}\left(\mathrm{~cm}^{-3}\right)$ in 26 observed strong dust events.

\begin{tabular}{|c|c|c|c|c|}
\hline Date & CALIPSO dust ratio (\%) & $N_{D, d>500 \mathrm{~nm}}\left(\mathrm{~cm}^{-3}\right)$ & Top 25\% & Top 10\% \\
\hline 2007-02-19 & 10.40 & 0.305 & $\mathrm{~V}$ & $\mathrm{~V}$ \\
\hline 2007-10-17 & 10.13 & 0.326 & $\mathrm{~V}$ & v \\
\hline 2007-11-18 & 10.21 & 0.204 & $\mathrm{~V}$ & v \\
\hline $2008-04-26$ & 12.81 & 1.840 & $\mathrm{v}$ & v \\
\hline $2008-05-12$ & 47.79 & 4.241 & $\mathrm{v}$ & v \\
\hline $2009-01-23$ & 14.46 & 0.326 & $\mathrm{~V}$ & v \\
\hline $2009-04-29$ & 14.07 & 3.840 & $\mathrm{~V}$ & v \\
\hline $2009-11-23$ & 11.81 & 0.029 & $x$ & $x$ \\
\hline $2010-02-27$ & 14.21 & 0.200 & $\mathrm{~V}$ & v \\
\hline 2010-05-02 & 33.45 & 7.781 & $\mathrm{v}$ & v \\
\hline 2010-05-18 & 17.97 & 0.163 & $\mathrm{~V}$ & $x$ \\
\hline $2010-10-25$ & 10.11 & 0.106 & $\mathrm{~V}$ & $x$ \\
\hline 2011-02-14 & 17.11 & 0.201 & $\mathrm{~V}$ & v \\
\hline 2011-04-03 & 13.34 & 0.221 & $\mathrm{~V}$ & v \\
\hline 2011-04-19 & 46.09 & 1.505 & $\mathrm{~V}$ & v \\
\hline $2011-05-21$ & 13.11 & 0.921 & $\mathrm{~V}$ & v \\
\hline $2012-05-23$ & 13.83 & 0.381 & $\mathrm{~V}$ & v \\
\hline 2014-10-04 & 12.30 & 2.823 & v & v \\
\hline $2015-02-25$ & 21.48 & 0.553 & $\mathrm{~V}$ & v \\
\hline 2015-04-14 & 14.59 & 2.736 & $\mathrm{~V}$ & v \\
\hline $2015-04-30$ & 11.73 & 0.600 & $\mathrm{~V}$ & v \\
\hline 2017-03-02 & 26.63 & 0.667 & $\mathrm{~V}$ & v \\
\hline 2017-05-05 & 13.37 & 1.549 & $\mathrm{~V}$ & v \\
\hline 2018-02-01 & 44.61 & 0.116 & $\mathrm{~V}$ & $x$ \\
\hline $2018-02-17$ & 11.90 & 0.144 & $\mathrm{~V}$ & $x$ \\
\hline $2018-03-21$ & 37.65 & 6.185 & $\mathrm{~V}$ & V \\
\hline
\end{tabular}




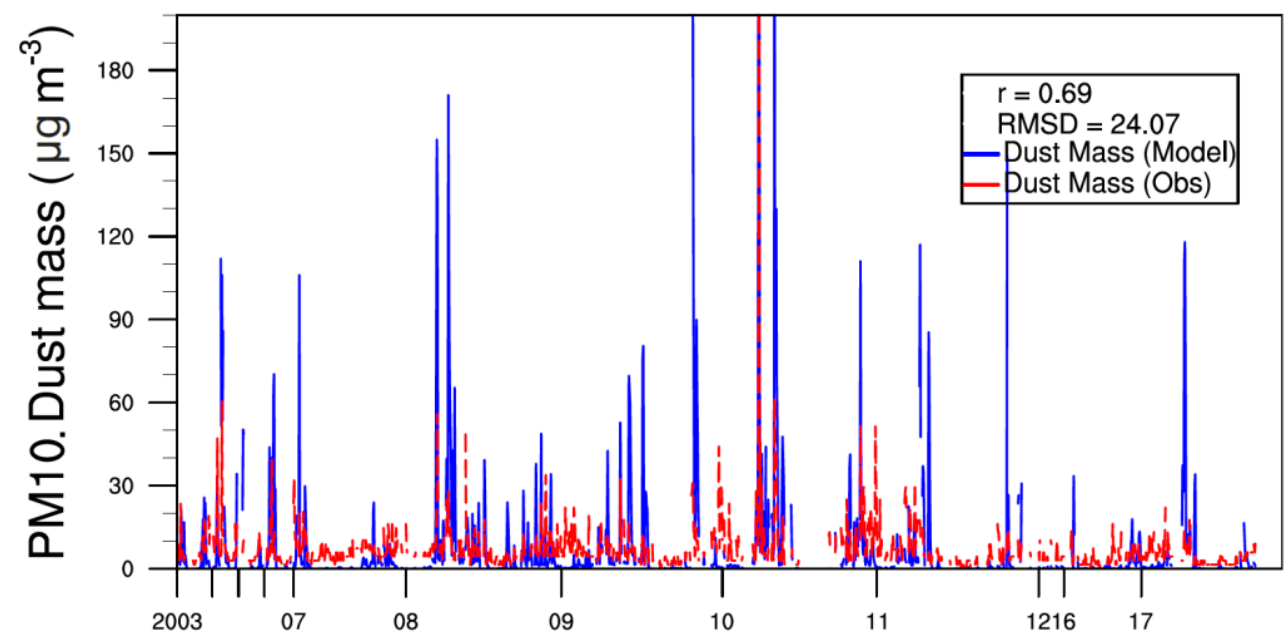

Fig. 2. Comparison of 2003-2017 surface level $P_{10}$ dust concentration between in-situ measurements (red line) and GEOS-Chem-APM (blue line). Dust mass is measured at the Cape Fuguei Research Station and GEOS-Chem-APM dust mass simulation is output for the Taipei site, near the observation station.

underestimation in weak dust event days may be caused by (1) the Calcium ion mass concentration of non-mineral dust is involved in observation; (2) in the GEOS-Chem model, the local dust emission over Taiwan is underestimated, such as the wintertime river-dust emission in Taiwan (Lin et al., 2018); and (3) the uncertainties associated to the mass mixing ratio of calcium in dust particles. Nevertheless, the overall well agreement between dust observation and simulation suggests that the GEOS-Chem-APM model can simulate the mineral dust temporal variation and the occurrence of strong dust events over the Taiwan region.

\section{RESULTS AND DISCUSSIONS}

\subsection{The Temporal and Spatial Properties of Dust Aerosols over Taiwan}

As mentioned in the Model and data Section, daily (local time, converted from hourly data) $N_{D, d}>500 \mathrm{~nm}$ simulations are output at two sites of $\operatorname{LLN}\left(23.47^{\circ} \mathrm{N}, 120^{\circ} \mathrm{E}\right)$ and Taipei $\left(25.09^{\circ} \mathrm{N}\right.$, $121.56^{\circ} \mathrm{E}$ ), covering the whole of Taiwan region. $N_{D, d}>500 \mathrm{~nm}$ simulations at the two grids are averaged to represent the atmospheric dust loading over Taiwan. Fig. 3 shows the 20-years (1999-2018) $N_{D, d}>500 \mathrm{~nm}$ simulations at different altitudes over the Taiwan region. Fig. 3 exhibits that dust transport events have a significant influence on atmospheric dust loading in Taiwan, with $N_{D, d}>500 \mathrm{~nm}$ varying by 2-3 orders of magnitude from clean to adjacent dust events days in the same seasons. The result also indicates significant annual and seasonal variations of $N_{D, d}>500 \mathrm{~nm}$ : annually, the maximum $N_{D, d>500 \mathrm{~nm}}$ in different years can vary by about ten times (from $38.4 \mathrm{~cm}^{-3}$ in 2010 to $6.8 \mathrm{~cm}^{-3}$ in 2009); seasonally, the frequencies of strong dust event in spring and fall are much higher than that in summer and winter. At most times, $N_{D, d}>500 \mathrm{~nm}$ at the surface (the black line), $1 \mathrm{~km}$ (blue), and $2 \mathrm{~km}$ (orange) are much stronger than that at higher levels, indicating that dust transporting events over Taiwan primarily occur at low latitudes. Below we focus on the typical value, seasonal variation, and long-term trend of dust aerosols over the Taiwan area.

\subsection{Seasonal Variations and Vertical Properties of Mineral Dust}

Fig. 3 shows significant seasonal and vertical variations of $N_{D, d}>500 \mathrm{~nm}$ over the Taiwan region, that are specifically described by the monthly averaged GEOS-Chem simulations of $N_{D, d>500 \mathrm{~nm}}$ given in Fig. 4 . The monthly mean $N_{D, d}>500 \mathrm{~nm}$ at six selected height levels show a bimodal seasonal distribution, with the strongest dust signal occurring in spring (MAM) and a weaker peak value of $N_{D, d}>500 \mathrm{~nm}$ in fall (ON), and the lowest dust loading occurs in summer (JJA). In the different seasons, $N_{D, d>500 \mathrm{~nm}}$ varies by about one order of magnitude from summer to spring (0.06$1.23 \mathrm{~cm}^{-3}$ in the boundary layer, $0.03-0.55 \mathrm{~cm}^{-3}$ in the middle and lower troposphere, and $0.006-$ 


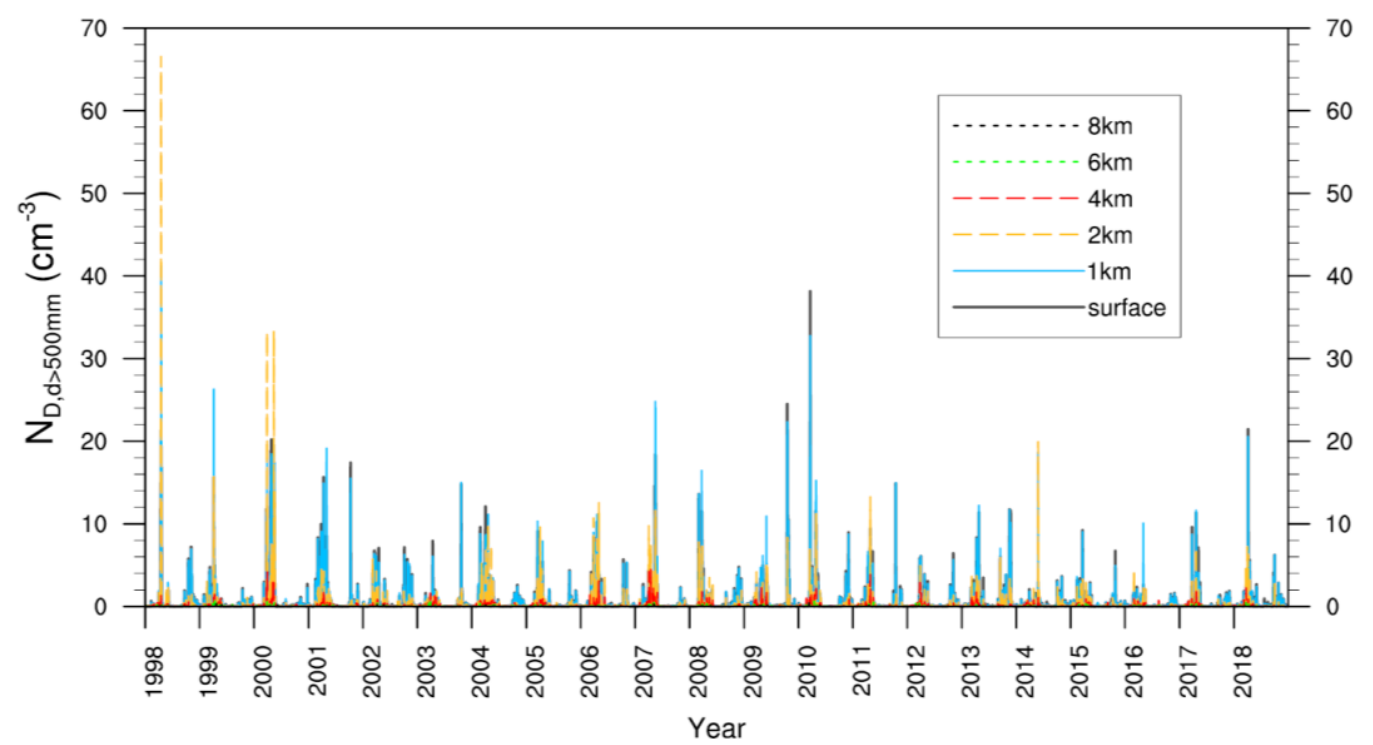

Fig. 3. 20-year (1999-2018) GEOS-Chem-APM simulated daily mean $N_{D, d>500 \mathrm{~nm}}$ at different model layers/levels (black: surface layer; light blue: $1 \mathrm{~km}$; orange: $2 \mathrm{~km}$; red: $4 \mathrm{~km}$; green: $6 \mathrm{~km}$; grey: $8 \mathrm{~km})$.

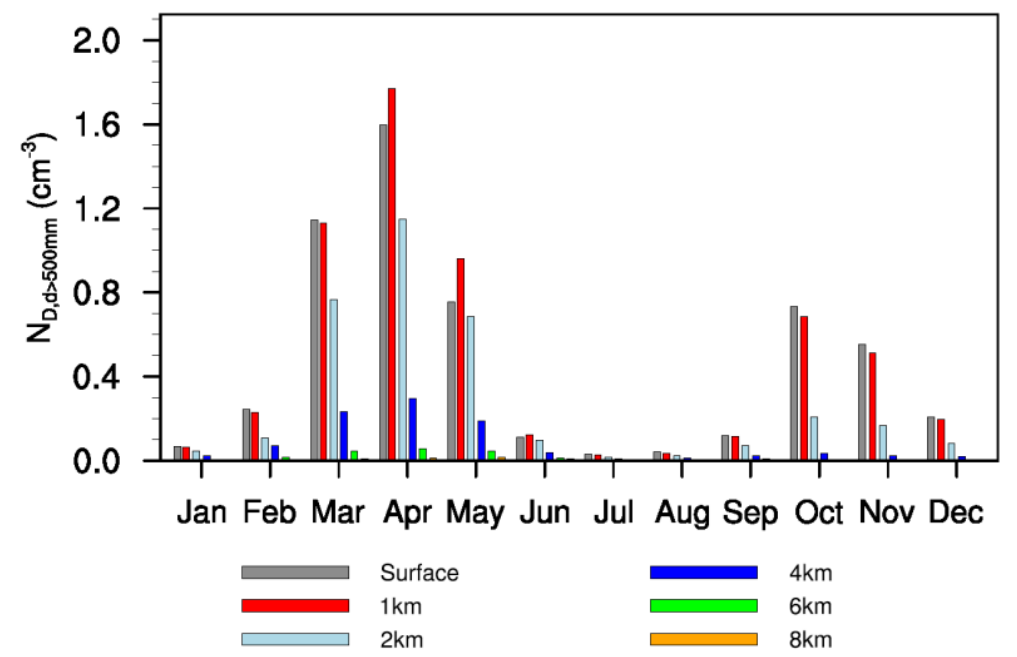

Fig. 4. Monthly $N_{D, d>500 \mathrm{~nm}}\left(\mathrm{~cm}^{-3}\right)$ at different vertical levels for each month averaged during the 20 years.

$0.03 \mathrm{~cm}^{-3}$ in the upper level). In a year, the monthly mean $N_{D, d}>500 \mathrm{~nm}$ has the highest value in April $\left(\sim 1.77 \mathrm{~cm}^{-3}\right)$, and $N_{D, d>500 \mathrm{~nm}}$ is the lowest in July $\left(\sim 0.03 \mathrm{~cm}^{-3}\right)$ which is two orders of magnitude smaller than that in April. Fig. 4 also suggests a unimodal vertical distribution of atmospheric dust aerosols over Taiwan, with monthly mean $N_{D, d>500 \mathrm{~nm}}$ having the peak value at lower levels (surface $1 \mathrm{~km}$ ).

To further study the typical values and vertical distributions of mineral dust over Taiwan, we choose the lower $10 \%$ and lower quartile of $N_{D, d}>500 \mathrm{~nm}$ at each level to represent the dust number concentrations in weak dust days in specific seasons, and the upper quartile and upper $10 \%$ to represent those in strong dust days. The statistical results are essential to providing a profound understanding of atmospheric dust aerosol and can be used in numerical studies for heterogeneous ice nucleation calculation. Fig. 5 shows that, in the four seasons, dust concentrations in both clean and dusty days have similar distribution properties, with peak $N_{D, d}>500 \mathrm{~nm}$ appearing at low altitude, and decreasing with height. In spring, fall, and winter, $N_{D, d}>500 \mathrm{~nm}$ decreases by about two orders of magnitude from low to high elevations; in summer, $N_{D, d}>500 \mathrm{~nm}$ varies by roughly an order 

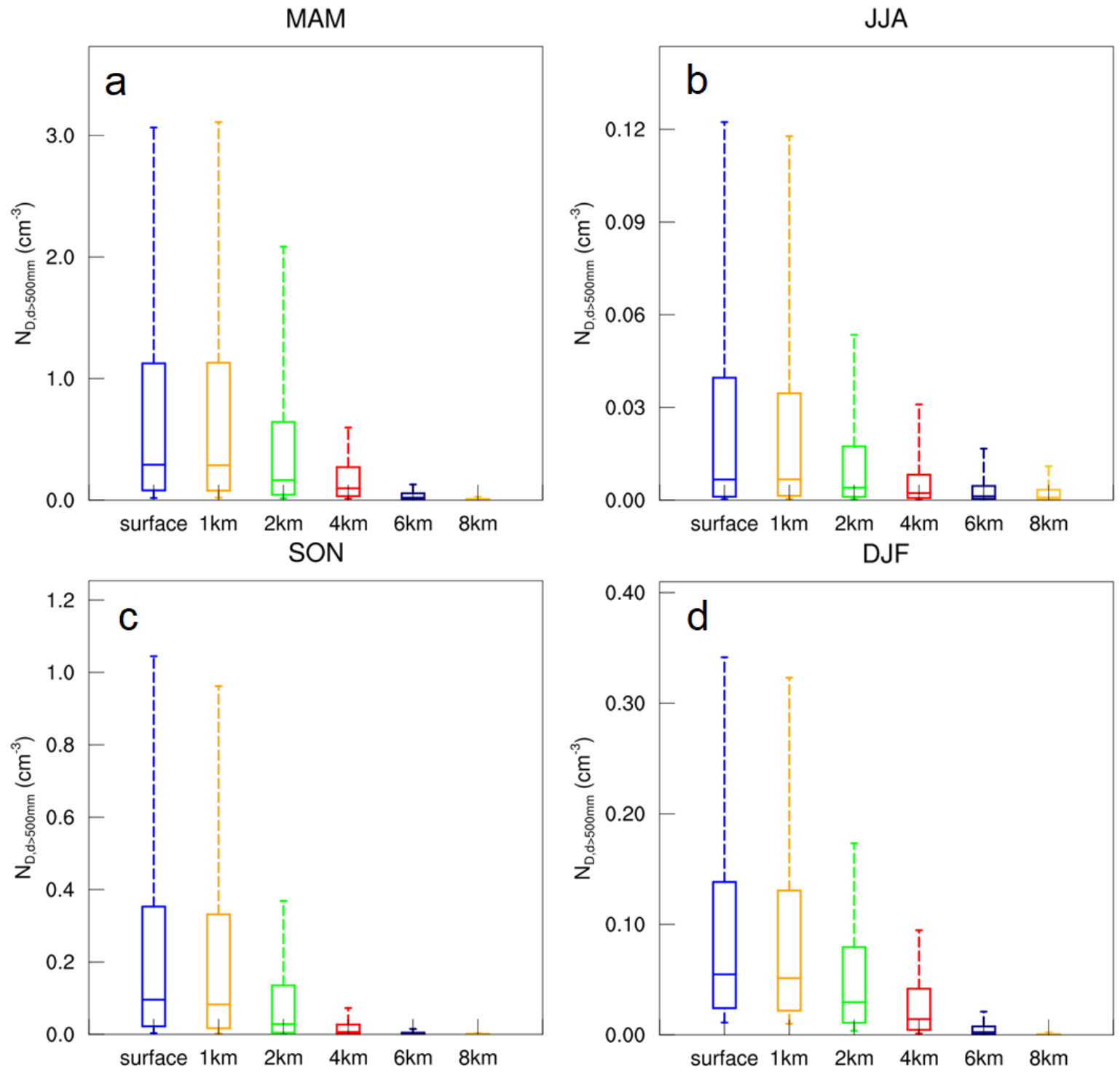

Fig. 5. The lower $10 \%$, lower quartile, median, upper quartile, and upper $10 \%$ values of $N_{D, d}>500 \mathrm{~nm}$ at surface (blue), $1 \mathrm{~km}$ (orange), $2 \mathrm{~km}$ (green), $4 \mathrm{~km}$ (red), $6 \mathrm{~km}$ (navy blue), and $8 \mathrm{~km}$ (yellow) levels in spring (a), summer (b), fall (c) and winter (d).

of magnitude, less dramatically than in other seasons. Fig. 5 shows the significant distinctions between clean and dusty days, with $N_{D, d}>500 \mathrm{~nm}$ varying by 2-3 orders of magnitude at each level in the same season. On clean days, dust number concentrations are lower than $0.1 \mathrm{~cm}^{-3}$, which have limited influences on air quality and cloud development. In dust days, $N_{D, d}>500 \mathrm{~nm}$ can reach higher than $3 \mathrm{~cm}^{-3}$ in the boundary layer, which could influence that air quality and public health (Uematsu et al., 1983; Li et al., 1996; Cheng et al., 2005; Liu et al., 2006; Chiu et al., 2008); and the $N_{D, d}>500 \mathrm{~nm}$ can reach about $0.2-2 \mathrm{~cm}^{-3}$ in the middle and high levels. Previous laboratory experiments suggest that the activation ratio of mineral dust is about $0.5-3 \%$ at $\sim-20^{\circ} \mathrm{C}$ (Zimmermann et al., 2008; Niemand et al., 2012), the dust-contributed INP number concentration can reach about 1-60 $\mathrm{L}^{-1}$ over Taiwan, high enough to substantially influence the development of cloud and precipitation (Creamean et al., 2013; Fan et al., 2014).

Previous studies indicate that the atmospheric dust loading is highly influenced by the intermittent long-range transport of dust from mainland China, the Middle East, and Sahara (Chen et al., 2003; Hsu et al., 2012; Lin et al., 2012; Chou et al., 2017). We choose the mean values of $N_{D, d}>500 \mathrm{~nm}$ during the top $25 \%, 10 \%$, and $1 \%$ dust events at the six levels for four seasons during 1999-2018, to represent the strength of dust events, strong dust events, and extreme dust events, respectively. The mean and maximum $N_{D, d}>500 \mathrm{~nm}$ at the six levels in four seasons are 
also listed. The statistical results are given in Tables $2-5$. Table 2 shows that in spring (MAM), the mean value varies from $0.012 \mathrm{~cm}^{-3}(8 \mathrm{~km})$ to $1.281 \mathrm{~cm}^{-3}(1 \mathrm{~km})$; from the mean state, $N_{D, d>500 \mathrm{~nm}}$ can increase by $\sim 3,5,17$ times during dust events, strong and extreme events, respectively. In summer (JJA) (Table 3), the dust has the lowest number concentration over the year, with the mean $N_{D, d>500 \mathrm{~nm}}$ of about $0.005(8 \mathrm{~km}) \sim 0.062 \mathrm{~cm}^{-3}(1 \mathrm{~km})$ although $N_{D, d>500 \mathrm{~nm}}$ during extreme dust events can be a factor of $\sim 30$ higher. The result suggests that although the mean $N_{D, d}>500 \mathrm{~nm}$ is lower than in other seasons, the transport of dust in summer has more significant contributions to the atmospheric dust loading over Taiwan. In fall (SON) (Table 3), vertically, the mean values at different heights vary from 0.471 (surface) to $0.002 \mathrm{~cm}^{-3}(8 \mathrm{~km})$, and from the mean value, $N_{D, d}>500 \mathrm{~nm}$ increases by $\sim 3,6,20$ times when dust events, strong and extreme events occur. In winter (Table 5), $N_{D, d}>500 \mathrm{~nm}$ at low altitudes (surface-2 $\mathrm{km}$ ) is much higher than that in summer, but lower at higher altitudes $(6-8 \mathrm{~km})$. In Fig. 5 and Tables $2-5$, the results suggest the shifting vertical properties of dust particles, that in spring and summer, the highest $N_{D, d>500 \mathrm{~nm}}$ appears at

Table 2. $N_{D, d>500 \mathrm{~nm}}$ simulations at 6 height levels in different dust events in spring (MAM).

\begin{tabular}{lllllll}
\hline$N_{D, d>500 \mathrm{~nm}}\left(\mathrm{~cm}^{-3}\right)$ & Surface & $1 \mathrm{~km}$ & $2 \mathrm{~km}$ & $4 \mathrm{~km}$ & $6 \mathrm{~km}$ & $8 \mathrm{~km}$ \\
\hline Mean & 1.161 & $\mathbf{1 . 2 8 1}$ & 0.864 & 0.239 & 0.051 & 0.012 \\
Dust Events (upper 25\%) & 3.811 & $\mathbf{4 . 3 2 4}$ & 2.997 & 0.714 & 0.151 & 0.038 \\
Strong Events (upper 10\%) & 5.969 & $\mathbf{6 . 8 9 5}$ & 4.960 & 1.055 & 0.224 & 0.061 \\
Extreme Events (upper 1\%) & 16.488 & $\mathbf{2 1 . 9 0 0}$ & 19.143 & 2.824 & 0.519 & 0.194 \\
Maximum & 38.150 & 41.200 & $\mathbf{6 6 . 5 5 0}$ & 4.46 & 0.7295 & 0.44635 \\
\hline
\end{tabular}

Note. Mean $N_{D, d>500 \mathrm{~nm}}$ during dust events (at the upper $25 \%$ of overall 7305 days), strong dust events (at the upper $10 \%$ ), and extreme events (at the upper 1\%) as well as maximum $N_{D, d>500 \mathrm{~nm}}$ at 6 height model levels in spring (MAM). The peak value in each dust event category is marked with shadow.

Table 3. $N_{D, d>500 \mathrm{~nm}}$ simulations at 6 height levels in different dust events in summer (JJA).

\begin{tabular}{lllllll}
\hline$N_{D, d>500 \mathrm{~nm}}\left(\mathrm{~cm}^{-3}\right)$ & Surface & $1 \mathrm{~km}$ & $2 \mathrm{~km}$ & $4 \mathrm{~km}$ & $6 \mathrm{~km}$ & $8 \mathrm{~km}$ \\
\hline Mean & 0.061 & $\mathbf{0 . 0 6 2}$ & 0.044 & 0.019 & 0.008 & 0.005 \\
Dust Events (Upper 25\%) & 0.221 & $\mathbf{0 . 2 2 6}$ & 0.164 & 0.070 & 0.028 & 0.016 \\
Strong Events (Upper 10\%) & 0.378 & $\mathbf{0 . 3 9 1}$ & 0.300 & 0.125 & 0.047 & 0.026 \\
Extreme Events (Upper 1\%) & 1.884 & $\mathbf{2 . 0 2 9}$ & 1.972 & 0.599 & 0.167 & 0.094 \\
Maximum & 4.024 & $\mathbf{6 . 0 4 1}$ & 4.755 & 1.151 & 0.295 & 0.266 \\
\hline
\end{tabular}

Note. Same variables as in table 2, but in summer (JJA).

Table 4. $N_{D, d>500 \mathrm{~nm}}$ simulations at 6 height levels in different dust events in fall (SON).

\begin{tabular}{lllllll}
\hline$N_{D, d>500 \mathrm{~nm}}\left(\mathrm{~cm}^{-3}\right)$ & Surface & $1 \mathrm{~km}$ & $2 \mathrm{~km}$ & $4 \mathrm{~km}$ & $6 \mathrm{~km}$ & $8 \mathrm{~km}$ \\
\hline Mean & $\mathbf{0 . 4 7 1}$ & 0.440 & 0.150 & 0.027 & 0.006 & 0.002 \\
Dust Events (Upper 25\%) & $\mathbf{1 . 6 2 1}$ & 1.532 & 0.512 & 0.092 & 0.021 & 0.006 \\
Strong Events (Upper 10\%) & $\mathbf{2 . 7 0 9}$ & 2.561 & 0.816 & 0.143 & 0.034 & 0.011 \\
Extreme Events (Upper 1\%) & $\mathbf{1 1 . 2 0 1}$ & 10.711 & 2.686 & 0.362 & 0.105 & 0.037 \\
Maximum & $\mathbf{2 4 . 5 0 0}$ & 22.350 & 8.345 & 0.557 & 0.255 & 0.077 \\
\hline
\end{tabular}

Note. Same variables as in table 2 , but in fall (SON).

Table 5. $N_{D, d>500 \mathrm{~nm}}$ simulations at 6 height levels in different dust events in winter (DJF).

\begin{tabular}{lllllll}
\hline$N_{D, d>500 \mathrm{~nm}}\left(\mathrm{~cm}^{-3}\right)$ & Surface & $1 \mathrm{~km}$ & $2 \mathrm{~km}$ & $4 \mathrm{~km}$ & $6 \mathrm{~km}$ & $8 \mathrm{~km}$ \\
\hline Mean & $\mathbf{0 . 1 6 9}$ & 0.160 & 0.044 & 0.037 & 0.009 & 0.001 \\
Dust Events (Upper 25\%) & $\mathbf{0 . 5 3 8}$ & 0.511 & 0.239 & 0.113 & 0.028 & 0.004 \\
Strong Events (Upper 10\%) & $\mathbf{0 . 8 7 8}$ & 0.836 & 0.369 & 0.167 & 0.045 & 0.006 \\
Extreme Events (Upper 1\%) & $\mathbf{3 . 6 4 7}$ & 3.545 & 1.359 & 0.496 & 0.156 & 0.024 \\
Maximum & $\mathbf{9 . 6 3 0}$ & 8.800 & 3.040 & 1.010 & 0.387 & 0.070 \\
\hline
\end{tabular}

Note. Same variables as in table 2, but in winter (DJF). 
a higher altitude than in fall and winter. The shift of the dust sources and transport modes could be important factors of this seasonal variation. It is also notable that, although $N_{D, d}>500 \mathrm{~nm}$ at $4-8$ $\mathrm{km}$ is much lower than that at lower levels, middle-high level $N_{D, d>500 \mathrm{~nm}}$ can reach more than $0.1 \mathrm{~cm}^{-3}$ and $0.4 \mathrm{~cm}^{-3}$ when dust events and extreme events happen. Influenced by the dynamic uplifting of terrain and convection systems, $N_{D, d}>500 \mathrm{~nm}$ at the middle-high level could be even higher. Due to the low atmospheric temperatures at the middle and upper troposphere, dust particles could impact the cloud development through heterogeneous freezing and convective invigoration (DeMott et al., 2003; Andreae et al., 2004; Creamean et al., 2013; Fan et al., 2014).

Considering the importance of dust events over Taiwan, the strong dust events are studied in aspects of both frequency and strength, which are factors influencing the atmospheric dust aerosol loading. Strong dust events (top 10\%) usually last for a couple of days, in this research a single day is defined as "an event day", and the number of days is used to represent the frequency of dust events.

Fig. 6 shows the frequencies (columns) and $N_{D, d}>500 \mathrm{~nm}$ (dashed lines) of strong dust events at six selected altitudes. The GEOS-Chem-APM model results (Figs. 6(a), 6(b), and 6(c)) show the bimodal seasonal distributions of strong dust events at low altitude (surface, $1 \mathrm{~km}$, and $2 \mathrm{~km}$ ), with high frequencies and concentrations mainly occur in spring (March, April, and May), and fallwinter (October, November, and December). At surface and $1 \mathrm{~km}$ levels, there are more strong dust events in spring, about twice that in fall and winter. However, the dust event strengths are close in spring (with highest $N_{D, d>500 \mathrm{~nm}}=4.29 \mathrm{~cm}^{-3}$ at the surface and $4.76 \mathrm{~cm}^{-3}$ at $1 \mathrm{~km}$ occur in April) and fall (with highest $N_{D, d>500 \mathrm{~nm}}=4.10 \mathrm{~cm}^{-3}$ at the surface and $3.89 \mathrm{~cm}^{-3}$ at $1 \mathrm{~km}$ occur in October). The result reveals that, although the frequency of dust events in fall and winter is lower than in spring, when dust storm happens, the atmospheric dust loading can be very high, influencing the environment and air quality over Taiwan. Fig. 6 shows that from the surface to high altitudes, the frequencies of strong dust storm events gradually increase in summer and early fall (JJAS) and decrease in late fall and winter (OND). Strong dust events at the middle troposphere $(4,6$, and $8 \mathrm{~km})$ show the unimodal seasonal variation; this pattern could be clearly distinguished from the boundary layer. The GEOS-Chem-APM model results exhibit different seasonal patterns of strong dust events at low (surface, 1 and $2 \mathrm{~km}$ ) and middle-upper troposphere $(4,6$, and $8 \mathrm{~km})$, which may be caused by the various sources and heights of dust transport. The long-range transport of dust from east Asia at low altitudes during late winter and spring has been investigated by previous observation and modeling studies (Chen et al., 2004; Lin et al., 2012). In the mid-to-upper troposphere over Taiwan, dust might have a strong contribution from the Middle East and Sahara (Hsu et al., 2012). A recent study also indicates the river-dust event as a local source of dust during the wintertime (Lin et al., 2018).

\subsection{The Long-term Trend of Dust Aerosols over Taiwan}

The above results show that the properties of dust events vary at different vertical levels. Accordingly, the dust event frequency and strength are used to study the long-term trend of atmospheric dust aerosols at each level over the Taiwan region. The number of dust event days (NOE) with the top $10 \% N_{D, d}>500 \mathrm{~nm}$ of overall 7305 days (1999-2018) is used to represent the frequency of strong dust events, and the annual mean $N_{D, d>500 n m}$ represents the atmospheric dust loading.

Figs. $7(a), 7(b), 7(c)$, and $7(d)$ show the significant decreasing trends of dust event frequency at low levels (under $4 \mathrm{~km}$ ), with NOEs from 1999 to 2018 decrease by $40.5 \%$ (0.98 days $\mathrm{yr}^{-1}$ ), $41.1 \%\left(1.00\right.$ days $\left.\mathrm{yr}^{-1}\right), 36.8 \%\left(0.87\right.$ days $\left.\mathrm{yr}^{-1}\right)$ and $43.0 \%$ (1.06 days $\left.\mathrm{yr}^{-1}\right)$ at the surface, 1,2 and $4 \mathrm{~km}$ levels, respectively. Similarly, atmospheric dust loadings over Taiwan also show the strong downward tendencies, with annual mean $N_{D, d}>500 \mathrm{~nm}$ decrease by $40.3 \%\left(0.012 \mathrm{~cm}^{-3} \mathrm{yr}^{-1}\right), 45.9 \%$ $\left(0.016 \mathrm{~cm}^{-3} \mathrm{yr}^{-1}\right), 54.0 \%\left(0.011 \mathrm{~cm}^{-3} \mathrm{yr}^{-1}\right)$ and $37.2 \%\left(-0.002 \mathrm{~cm}^{-3} \mathrm{yr}^{-1}\right)$ at surface, 1,2 and $4 \mathrm{~km}$ levels. The tendencies of decreasing are weaker at higher altitudes, NOEs decrease by $14.7 \%$ and $11.5 \%$, and $N_{D, d}>500 \mathrm{~nm}$ decrease by $30.9 \%$ and $32.7 \%$ at 6 and $8 \mathrm{~km}$ levels, respectively. The result shows the general decreasing trends of both strong dust event frequencies and dust loading in the last two decades, which shows distinct characteristics at low and mid-high altitudes. The declines of strong dust event frequency and dust loading are significant under $4 \mathrm{~km}$ (NOE decreases by $\sim 40 \%, N_{D, d}>500 \mathrm{~nm}$ decreases by $\sim 45 \%$ ), and weakening with altitudes (NOE decreases by $\sim 10 \%, N_{D, d}>500 \mathrm{~nm}$ decreases by $\left.\sim 30 \%\right)$. 


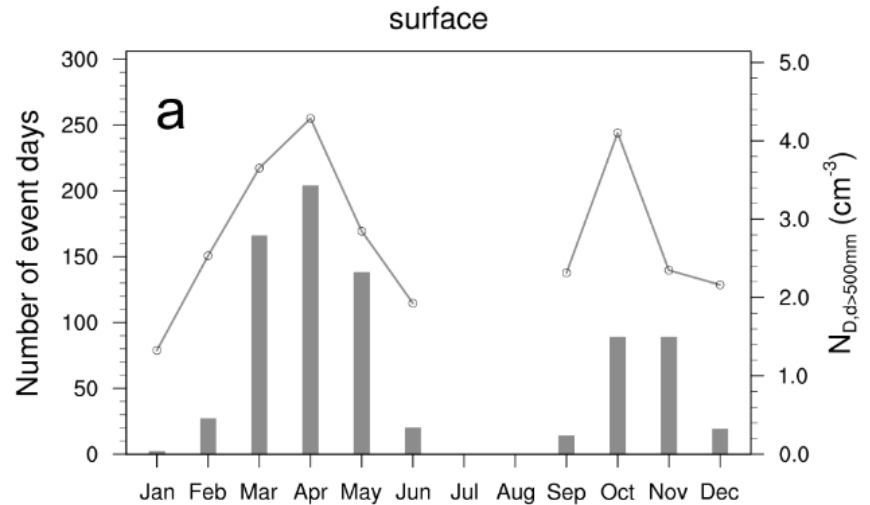

$1 \mathrm{~km}$

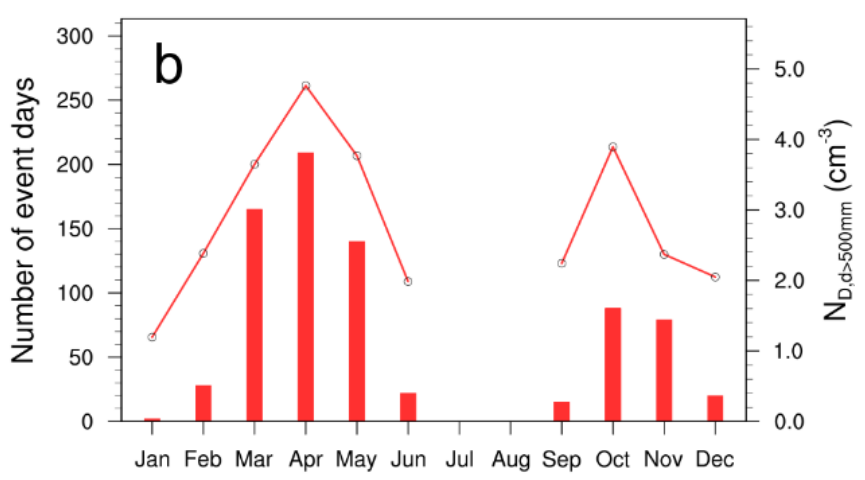

$2 \mathrm{~km}$

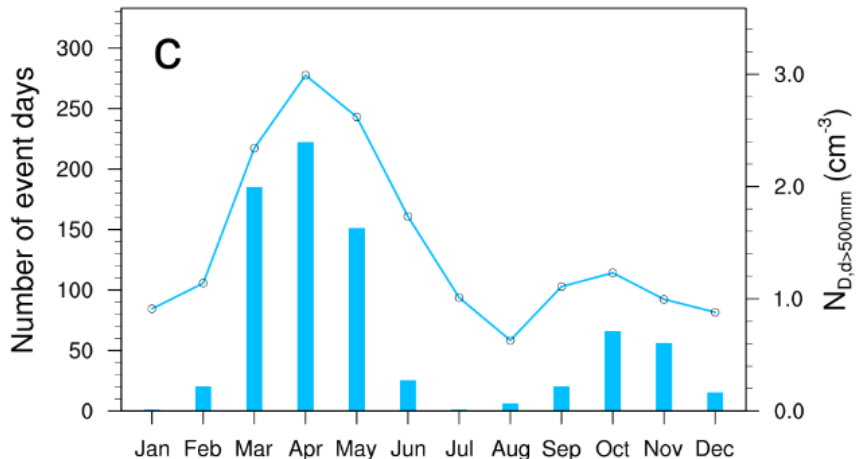

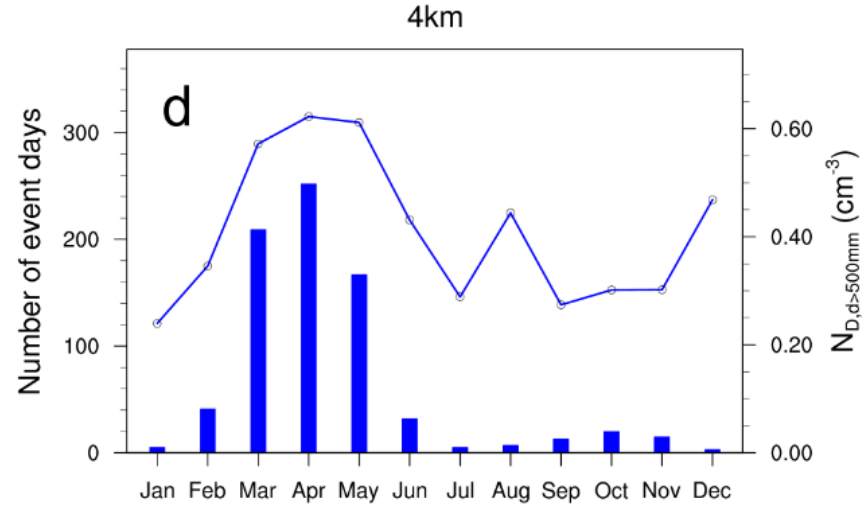
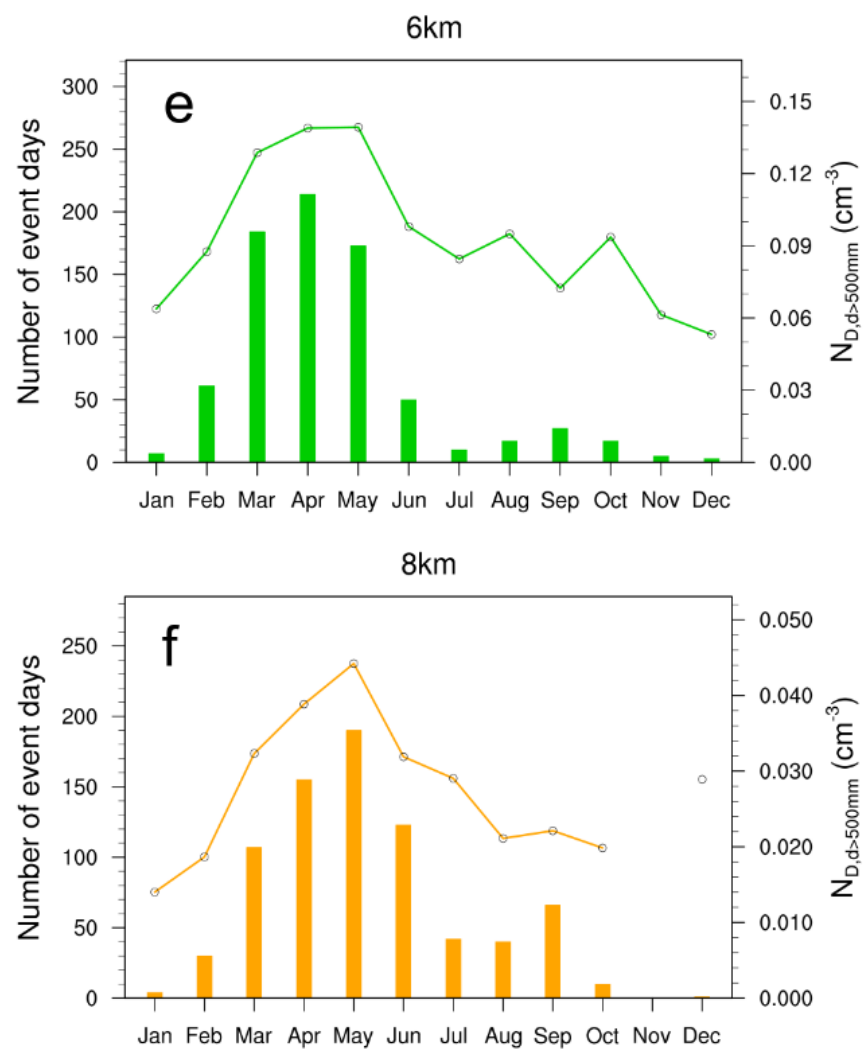

Fig. 6. Seasonal variations of the number of dust event days (bars) and $N_{D, d>500 n m}$ (lines) of strong dust events at (a) surface, (b) $1 \mathrm{~km}$, (c) $2 \mathrm{~km}$, (d) $4 \mathrm{~km}$, (e) $6 \mathrm{~km}$ and (f) $8 \mathrm{~km}$.

In Fig. 7 , it is also worth noting that NOE and $N_{D, d>500 \mathrm{~nm}}$ have different interannual variation characteristics at low (surface-4 $\mathrm{km}$ ) and high altitudes $(6-8 \mathrm{~km})$. The above results indicate that the highest $N_{D, d}>500 \mathrm{~nm}$ appears at the $1 \mathrm{~km}$ level. Thus, the correlation coefficients between dust variables at $1 \mathrm{~km}$ and other levels are calculated to quantitatively analyze the interannual variability at different altitudes. The result indicate that, dust event frequencies and annual mean $N_{D, d}>500 \mathrm{~nm}$ share similar characteristics at low altitudes (under $4 \mathrm{~km}$ ), with NOE correlation coefficients $\mathrm{r}_{\mathrm{NOE}}=0.99$ (surface), $0.82(2 \mathrm{~km}), 0.67(4 \mathrm{~km})$ and $N_{D, d>500 \mathrm{~nm}}$ correlation coefficients $r_{n c}=0.98$ (surface), $0.84(2 \mathrm{~km}), 0.74(4 \mathrm{~km})(p$-value $<0.001)$. NOE at higher levels have low correlation with that at $1 \mathrm{~km}$, with $\mathrm{r}_{\mathrm{NOE}}=0.24(6 \mathrm{~km})$ and $0.32(8 \mathrm{~km})$, however, that annual mean $N_{D, d>500 \mathrm{~nm}}$ shows relatively high correlation with $1 \mathrm{~km}$ dust, with $r_{\mathrm{nc}}=0.52(6 \mathrm{~km})$ and $0.5(8 \mathrm{~km})$ (p-value <0.05).

The decline of $N_{D, d}>500 \mathrm{~nm}$ over Taiwan is significant in the past two decades and it is worthwhile to analyze the underlying drivers for the decrease. Various reasons could contribute to this trend of dust loading over Taiwan, and we think one of the most important influencing factors is the 

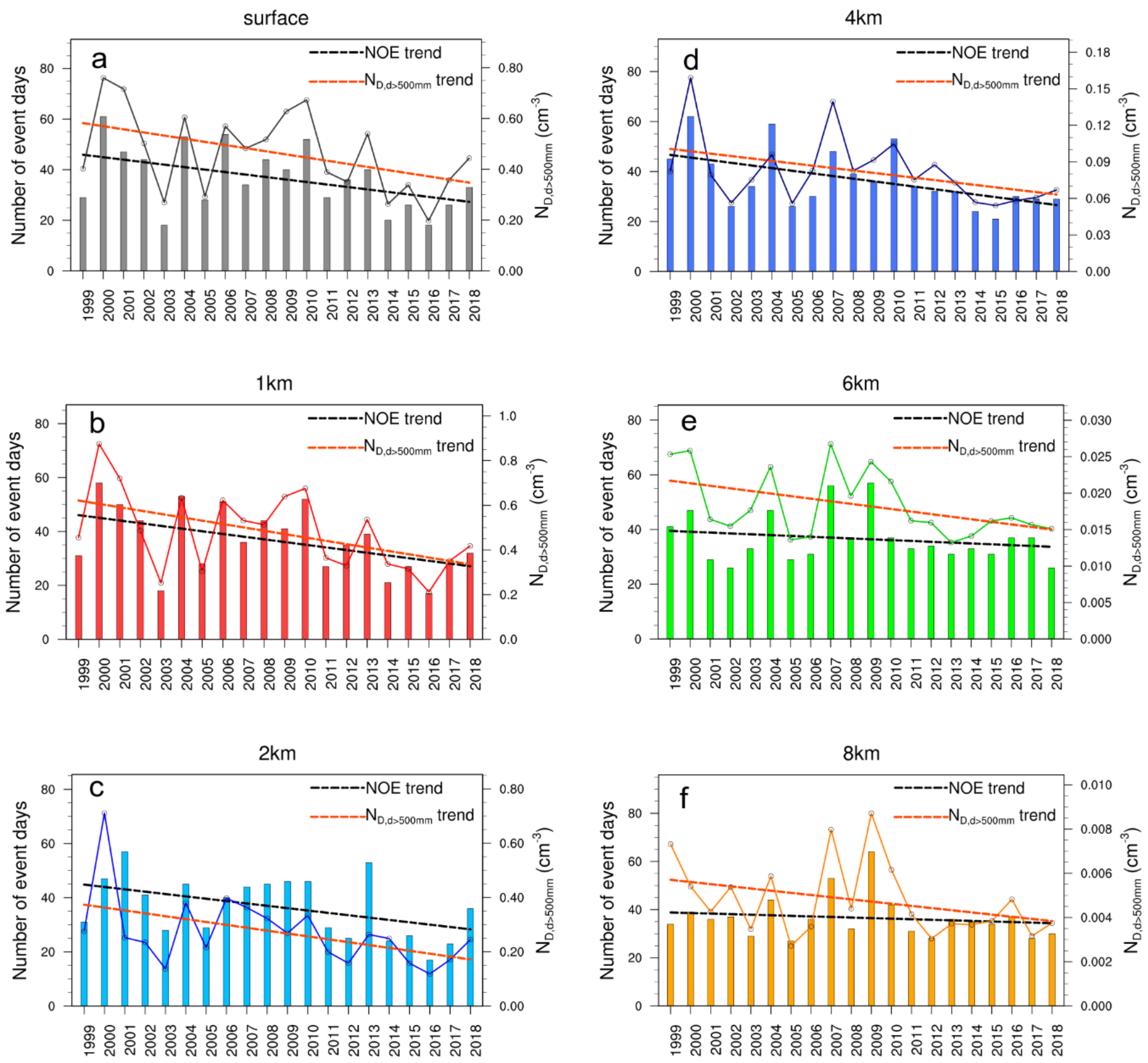

Fig. 7. Long-term (1999-2018) trends of annual mean $N_{D, d>500 n m}$ (solid line) and the dust numbers of strong dust event day (columns) at six levels. Broken lines are the linear trends of NOE (black) and $N_{D, d>500 \mathrm{~nm}}(\mathrm{red})$.

decreasing of East Asia dust emission. Previous studies indicate that the dust emission and outbreaks over East Asia show a notable downtrend over the past decades (Wang et al., 2008; Kurosaki et al., 2011; Wu et al., 2018). The trend has been suggested to be caused by various reasons, such as the increased vegetation coverage, the reduced spring cyclone frequency, the rising surface air temperature, etc.

To figure out the relationship between East Asian dust emission and atmospheric dust over the Taiwan region, the annual mean and springtime (the dustiest season) Asian dust emissions and $N_{D, d}>500 \mathrm{~nm}$ are given in Fig. 8 . Fig. 8 shows that the annual and springtime Asian dust emissions have similar interannual characteristics as the Taiwan $N_{D, d}>500 \mathrm{~nm}$ at lower levels, with $r=\sim 0.8$ and $\sim 0.7$ respectively, and dust emission also shows a similar decreasing trend as the Taiwan dust loading. Fig. 8(a) shows that the annual mean dust emission decreased by $\sim 12 \%$ (decreasing rate of $-0.01 \mathrm{~kg} \mathrm{~m}^{-2} \mathrm{yr}^{-1}$ ) from 1999 to 2018. In Fig. 8(b), the spring dust emission shows a more significant decline, which decreased by $\sim 17 \%$ (decreasing rate of $-0.03 \mathrm{~kg} \mathrm{~m}^{-2} \mathrm{yr}^{-1}$ ). The high 

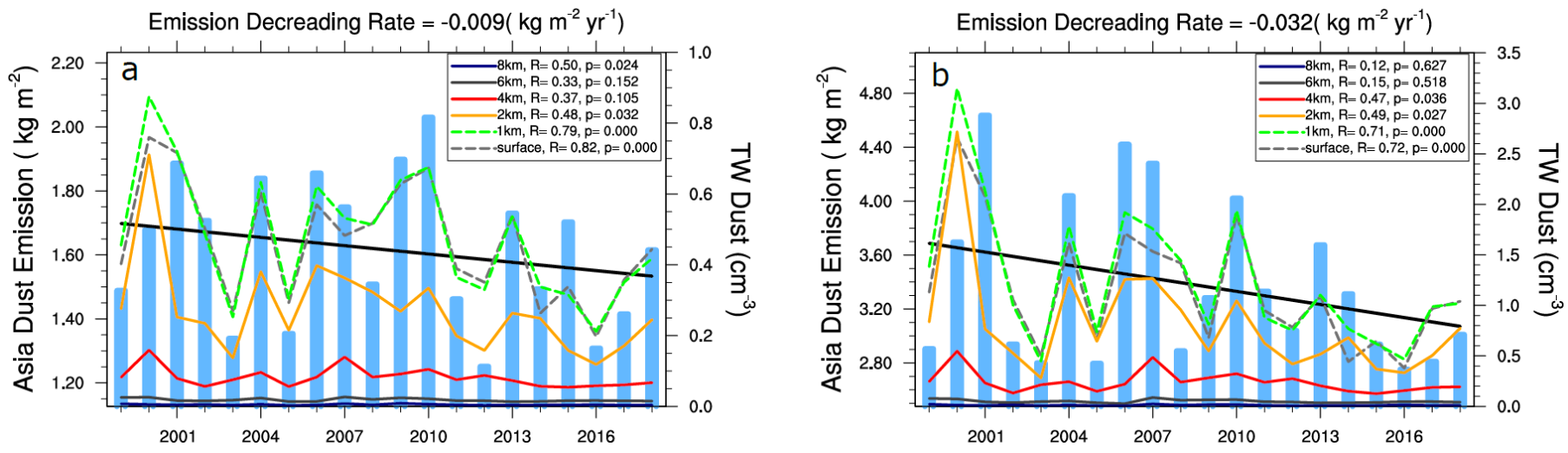

Fig. 8. (a) Annual and (b) spring mean dust emissions from East Asia (blue columns) and the atmospheric dust number concentrations over Taiwan at six levels (dashed lines). The black lines are the twenty-year trend (1999-2018) of dust emissions.

correlation between that dust emission and Taiwan $N_{D, d}>500 \mathrm{~nm}$ suggests that the decline of East Asian dust emission is one of the primary drivers of the $N_{D, d}>500 \mathrm{~nm}$ decreasing trend over the Taiwan region. Besides the Asian dust, we also analyzed other dust sources, such as Sahara and the Middle East. However, the analysis shows no obvious correlations between dust in Taiwan and these regions.

As discussed above, that strong dust event frequency and atmospheric dust loading have distinct decreasing trends and interannual variations at low and high altitudes. At the same time, Fig. 8 shows that the East Asian dust emission has a high correlation with dust aerosols from the surface to $2 \mathrm{~km}$, but with an insignificant correlation with dust at high altitudes. One possible reason is that the atmospheric dust over Taiwan has various transport modes at different heights. Previous studies indicate that, over Taiwan, mineral dust outflowed from East Asia is mainly under 4 km (Lin et al., 2007; Liu et al., 2009; Chang et al., 2010; Lin et al., 2012), and at the midto-upper troposphere, dust loading is influenced by the transport from the Middle East and Sahara (Hsu et al., 2012). At the same time, other possible reasons, such as the large-scale circulations, etc., may also influence the dust properties at different levels over Taiwan. Further studies will be processed to figure out possible influencing factors.

\section{CONCLUSIONS}

Based on the long-term (1999-2018) GEOS-Chem-APM model simulations, this study provides the seasonal variation, vertical properties, and long-term trend of the atmospheric dust aerosols over Taiwan. The 20-year model simulation is validated by comparing it with the in-situ dust measurement at the Cape Fuguei Research Station $\left(25.30^{\circ} \mathrm{N}, 121.54^{\circ} \mathrm{E}\right)$ at the northern tip of Taiwan Island (Chou et al., 2017).

The result reveals that the atmospheric dust loading in Taiwan is highly influenced by dust events and that $N_{D, d}>500 \mathrm{~nm}$ can vary by two orders of magnitude from clean to adjacent dusty days. During some extreme dust events, the $N_{D, d}>500 \mathrm{~nm}$ can reach more than $20 \mathrm{~cm}^{-3}$ which could significantly influence the public health, air quality, radiation budget, and the heterogeneous freezing of cloud ice particles. It can be seen from the long-term analysis that, the mineral dust shows clear seasonal characteristics with a bimodal distribution: monthly mean $N_{D, d}>500 \mathrm{~nm}$ and dust event frequencies are highest in spring (MAM) and fall-winter (ON). Monthly mean $N_{D, d>500 \mathrm{~nm}}$ varies by two orders of magnitude from the lowest value in July $\left(\sim 0.03 \mathrm{~cm}^{-3}\right)$ to the highest in April $\left(\sim 1.77 \mathrm{~cm}^{-3}\right)$. Vertically, the dust loading has the peak value at low altitude (at $\sim 1 \mathrm{~km}$ in spring-summer, and close to surface in fall-winter) and $N_{D, d}>500 \mathrm{~nm}$ decreases significantly with height. It is worth noting that the monthly variations of mineral dust are different at low and high altitudes. The result shows that from the surface to the $8 \mathrm{~km}$ level, the frequency of strong dust events declines in winter and increases in summer. By analyzing the twenty-year GEOS-Chem simulations, we find a long-term decreasing trend of mineral dust over the Taiwan region, both for the frequency of strong dust events and the annual mean dust number concentration. The 
result indicates that, over Taiwan, the number of strong dust event days (NOE) decreases by $\sim 40 \%$, and the annual mean $N_{D, d}>500 \mathrm{~nm}$ decrease by $\sim 45 \%$ at low levels (under $4 \mathrm{~km}$ ), and the decline tendency is less significant at upper levels $(6-8 \mathrm{~km})$, with NOE decreases by $\sim 12 \%$ and the annual mean $N_{D, d}>500 \mathrm{~nm}$ decrease by $\sim 30 \%$. At the same time, NOE and $N_{D, d}>500 \mathrm{~nm}$ also show different interannual variation patterns at low (surface-4 km) and high altitudes $(6-8 \mathrm{~km})$. The twentyyear (1999-2018) analysis shows a significant correlation between Asian dust emission and the $N_{D, d}>500 \mathrm{~nm}$ in this region. The long-range transported dust from Asia is the major source of the dust aerosols over Taiwan, and the decline of Asian dust emission is one of the primary drivers of the $N_{D, d}>500 \mathrm{~nm}$ decreasing trend in this region. Over Taiwan, the distinct seasonal characteristics and long-term trends of mineral dust at low and high altitudes suggest that the dust transport modes and sources may shift vertically and seasonally. Previous studies indicate that, over Taiwan, the long-term transport of dust from East Asia arrives Taiwan mainly under $4 \mathrm{~km}$ (Lin et al., 2007; Liu et al., 2009; Chang et al., 2010; Lin et al., 2012), and at the mid-to-upper troposphere, the atmospheric dust loading is influenced by the dust from the Middle East and Sahara (Hsu et al., 2012).

Numerous modeling and observational works indicate the impacts of mineral dust on climate and weather systems, and an increasing number of numerical models have taken account of dust aerosols. Our study reveals that, over Taiwan, the atmospheric dust loading is highly variable and can vary by about 1-3 orders of magnitude in different conditions. The significant space-time variations of mineral dust may result in significant impacts on cloud and precipitation, via direct and indirect effects, highlighting the necessity of more detailed and realistic dust number concentrations in the dust-aware weather forecasting models. We hope this study could provide some understandings of the properties and typical values of mineral dust over Taiwan and help to guide the assumptions of dust concentration in dust-related numerical studies.

\section{ACKNOWLEDGMENTS}

- This research was supported by the NSF Partnership for International Research and Education (PIRE) Program between the United States and Taiwan under grant OISE-1545917, and NASA under grants NNX17AG35G and 80NSSC19K1275.

- The GEOS-Chem model is a community model managed by the Atmospheric Chemistry Modeling Group at Harvard University with support from NASA. The work described in this paper is based on GEOS-Chem version 10-01. GEOS-Chem is a freely accessible community model that can be downloaded from http://acmg.seas.harvard.edu/geos/.

- $\quad$ The CALIPSO data used in this paper are obtained from the NASA Langley Research Center Atmospheric Science Data Center, and can be downloaded from https://eosweb.larc.nasa.go v/project/calipso/cal_lid_12_vfm_standard_v4_20.

- The long-term measurement of dust concentration at the Cape Fuguei Research Station is conducted by the Research Center of Environmental Changes (RCEC) with support from the Academia Sinica and the MOST, Taiwan.

\section{REFERENCES}

Achakulwisut, P., Shen, L., Mickley, L.J. (2017). What controls springtime fine dust variability in the western United States? Investigating the 2002-2015 increase in fine dust in the US Southwest. J. Geophys. Res. 122, 12-449. https://doi.org/10.1002/2017JD027208

Andreae, M.O., Rosenfeld, D., Artaxo, P., Costa, A.A., Frank, G.P., Longo, K.M., Silva-Dias, M.A.F.D. (2004). Smoking rain clouds over the Amazon. Science 303, 1337-1342. https://doi.org/10.11 26/science.1092779

Ault, A.P., Williams, C.R., White, A.B., Neiman, P.J., Creamean, J.M., Gaston, C.J., Ralph, F.M., Prather, K.A. (2011). Detection of Asian dust in California orographic precipitation. J. Geophys. Res. 116, D16205. https://doi.org/10.1029/2010JD015351

Chang, S.C., Chou, C.C.K., Chen, W.N., Lee, C.T. (2010). Asian dust and pollution transport-A comprehensive observation in the downwind Taiwan in 2006. Atmos. Res. 95, 19-31. https://doi.org/10.1016/j.atmosres.2009.07.012 
Chen, J.P., Wang, Z., Young, C.Y., Tsai, F., Tsai, I.C., Wang, G.J., Shieh, W.C., Lin, H.W., Huang, J.Y., Lu, M.J. (2004). Simulations of Asian yellow dust incursion over Taiwan for the Spring of 2002 and 2003. Terr. Atmos. Ocean. Sci. 15, 949-981. https://doi.org/10.3319/TA0.2004.15.5.949( ADSE)

Chen, Y.S., Yang, C.Y. (2005). Effects of Asian dust storm events on daily hospital admissions for cardiovascular disease in Taipei, Taiwan. J. Toxicol. Environ. Health Part A 68, 1457-1464. https://doi.org/10.1080/15287390590967388

Cheng, M.T., Lin, Y.C., Chio, C.P., Wang, C.F., Kuo, C.Y. (2005). Characteristics of aerosols collected in central Taiwan during an Asian dust event in spring 2000. Chemosphere 61, 1439-1450. https://doi.org/10.1016/j.chemosphere.2005.04.120

Chiu, H.F., Tiao, M.M., Ho, S.C., Kuo, H.W., Wu, T.N., Yang, C.Y. (2008). Effects of Asian dust storm events on hospital admissions for chronic obstructive pulmonary disease in Taipei, Taiwan. Inhalation Toxicol. 20, 777-781. https://doi.org/10.1080/08958370802005308

Chou, C.C.K., Hsu, W.C., Chang, S.Y., Chen, W.N., Chen, M.J., Huang, W.R., Huang, S.H., Tsai, C.Y., Chang, S.C., Lee, C.T., Liu, S.C. (2017). Seasonality of the mass concentration and chemical composition of aerosols around an urbanized basin in East Asia. J. Geophys. Res. 122, 20262042. https://doi.org/10.1002/2016JD025728

Creamean, J.M., Suski, K.J., Rosenfeld, D., Cazorla, A., DeMott, P.J., Sullivan, R.C., White, A.B., Ralph, F.M., Minnis, P., Comstock, J.M., Tomlinson, J.M., Prather, K.A. (2013). Dust and biological aerosols from the Sahara and Asia influence precipitation in the Western U.S. Science 339, 1572-1578. https://doi.org/10.1126/science.1227279

DeMott, P.J., Sassen, K., Poellot, M.R., Baumgardner, D., Rogers, D.C., Brooks, S.D., Prenni, A.J., Kreidenweis, S.M. (2003). African dust aerosols as atmospheric ice nuclei: AFRICAN DUST AEROSOLS AS ICE NUCLEI. Geophys. Res. Lett. 30, 1732. https://doi.org/10.1029/2003GL017410

DeMott, P.J., Prenni, A.J., Liu, X., Kreidenweis, S.M., Petters, M.D., Twohy, C.H., Richardson, M.S., Eidhammer, T., Rogers, D.C. (2010). Predicting global atmospheric ice nuclei distributions and their impacts on climate. PNAS 107, 11217-11222. https://doi.org/10.1073/pnas.0910818107

DeMott, P.J., Prenni, A.J., McMeeking, G.R., Sullivan, R.C., Petters, M.D., Tobo, Y., Niemand, M., Möhler, O., Snider, J.R., Wang, Z., Kreidenweis, S.M. (2015). Integrating laboratory and field data to quantify the immersion freezing ice nucleation activity of mineral dust particles. Atmos. Chem. Phys. 15, 393-409. https://doi.org/10.5194/acp-15-393-2015

Eidhammer, T., DeMott, P.J., Prenni, A.J., Petters, M.D., Twohy, C.H., Rogers, D.C., Stith, J., Heymsfield, A., Wang, Z., Pratt, K.A., Prather, K.A., Murphy, S.M., Seinfeld, J.H., Subramanian, R., Kreidenweis, S.M. (2010). Ice initiation by aerosol particles: Measured and predicted ice nuclei concentrations versus measured ice crystal concentrations in an orographic wave cloud. J. Atmos. Sci. 67, 2417-2436. https://doi.org/10.1175/2010JAS3266.1

Engelstaedter, S., Tegen, I., Washington, R. (2006). North African dust emissions and transport. Earth Sci. Rev. 79, 73-100. https://doi.org/10.1016/j.earscirev.2006.06.004

Fan, J., Leung, L.R., DeMott, P.J., Comstock, J.M., Singh, B., Rosenfeld, D., Tomlinson, J.M., White, A., Prather, K.A., Minnis, P., Ayers, J.K., Min, Q. (2014). Aerosol impacts on California winter clouds and precipitation during CalWater 2011: Local pollution versus long-range transported dust. Atmos. Chem. Phys. 14, 81-101. https://doi.org/10.5194/acp-14-81-2014

Fan, J., Wang, Y., Rosenfeld, D., Liu, X. (2016). Review of aerosol-cloud interactions: Mechanisms, significance, and challenges. J. Atmos. Sci. 73, 4221-4252. https://doi.org/10.1175/JAS-D-160037.1

Formenti, P., Rajot, J.L., Desboeufs, K., Caquineau, S., Chevaillier, S., Nava, S., Gaudichet, A., Journet, E., Triquet, S., Alfaro, S., Chiari, M., Haywood, J., Coe, H., Highwood, E. (2008). Regional variability of the composition of mineral dust from western Africa: Results from the AMMA SOPO/DABEX and DODO field campaigns. J. Geophys. Res. 113, D00C13. https://doi.org/10.1029/2008JD009903

Ganor, E., Stupp, A., Alpert, P. (2009). A method to determine the effect of mineral dust aerosols on air quality. Atmos. Environ. 43, 5463-5468. https://doi.org/10.1016/j.atmosenv.2009.07.028

Hand, J.L., White, W.H., Gebhart, K.A., Hyslop, N.P., Gill, T.E., Schichtel, B.A. (2016). Earlier onset of the spring fine dust season in the southwestern United States. Geophys. Res. Lett. 43, 40014009. https://doi.org/10.1002/2016GL068519

Hoose, C., Möhler, O. (2012). Heterogeneous ice nucleation on atmospheric aerosols: A review 
of results from laboratory experiments. Atmos. Chem. Phys. 12, 9817-9854. https://doi.org/1 0.5194/acp-12-9817-2012

Hsu, S.C., Liu, S.C., Huang, Y.T., Lung, S.C.C., Tsai, F., Tu, J.Y., Kao, S.J. (2008). A criterion for identifying Asian dust events based on Al concentration data collected from northern Taiwan between 2002 and early 2007. J. Geophys. Res. 113, D18306. https://doi.org/10.1029/2007JD009574

Hsu, S.C., Huh, C.A., Lin, C.Y., Chen, W.N., Mahowald, N.M., Liu, S.C., Chou, C.C.K., Liang, M.C., Tsai, C.J., Lin, F.J., Chen, J.P., Huang, Y.T. (2012). Dust transport from non-East Asian sources to the North Pacific. Geophys. Res. Lett. 39, L12804. https://doi.org/10.1029/2012GL051962

Huang, J., Minnis, P., Chen, B., Huang, Z., Liu, Z., Zhao, Q., Yi, Y., Ayers, J.K. (2008). Long-range transport and vertical structure of Asian dust from CALIPSO and surface measurements during PACDEX. J. Geophys. Res. 113, D23212. https://doi.org/10.1029/2008JD010620

Kanji, Z.A., Ladino, L.A., Wex, H., Boose, Y., Burkert-Kohn, M., Cziczo, D.J., Krämer, M. (2017). Overview of ice nucleating particles. Meteorol. Monogr. 58, 1.1-1.33. https://doi.org/10.1175/ AMSMONOGRAPHS-D-16-0006.1

Kurosaki, Y., Shinoda, M., Mikami, M. (2011). What caused a recent increase in dust outbreaks over East Asia?. Geophys. Res. Lett. 38, L11702. https://doi.org/10.1029/2011GL047494

Levin, Z., Ganor, E., Gladstein, V. (1996). The effects of desert particles coated with sulfate on rain formation in the eastern Mediterranean. J. Appl. Meteorol. 35, 1511-1523. https://doi.org/10.1175/1520-0450(1996)035<1511:TEODPC>2.0.CO;2

Li, X., Maring, H., Savoie, D., Voss, K., Prospero, J.M. (1996). Dominance of mineral dust in aerosol light-scattering in the North Atlantic trade winds. Nature 380, 416-419. https://doi.org/10.103 $8 / 380416 a 0$

Liao, H., Seinfeld, J.H. (1998). Radiative forcing by mineral dust aerosols: sensitivity to key variables. J. Geophys. Res. 103, 31637-31645. https://doi.org/10.1029/1998JD200036

Lin, C.Y., Liu, S.C., Chou, C.C.K., Liu, T.H., Lee, C.T., Yuan, C.S., Shiu, C.J., Young, C.Y. (2004). LongRange transport of Asian dust and air pollutants to Taiwan. Terr. Atmos. Ocean. Sci. 15, 759. https://doi.org/10.3319/TAO.2004.15.5.759(ADSE)

Lin, C.Y., Wang, Z., Chen, W.N., Chang, S.Y., Chou, C.C.K., Sugimoto, N., Zhao, X. (2007). Longrange transport of Asian dust and air pollutants to Taiwan: observed evidence and model simulation. Atmos. Chem. Phys. 7, 423-434. https://doi.org/10.5194/acp-7-423-2007

Lin, C.Y., Chou, C.C.K., Wang, Z., Lung, S.C., Lee, C.T., Yuan, C.S., Chen, W.N., Chang, S.Y., Hsu, S.C., Chen, W.C., Liu, S.C. (2012). Impact of different transport mechanisms of Asian dust and anthropogenic pollutants to Taiwan. Atmos. Environ. 60, 403-418. https://doi.org/10.1016/j.a tmosenv.2012.06.049

Lin, C.Y., Lee, Y.H., Kuo, C.Y., Chen, W.C., Sheng, Y.F., Su, C.J. (2018). Impact of river-dust events on air quality of western Taiwan during winter monsoon: Observed evidence and model simulation. Atmos. Environ. 192, 160-172. https://doi.org/10.1016/j.atmosenv.2018.08.048

Liu, C.M., Young, C.Y., Lee, Y.C. (2006). Influence of Asian dust storms on air quality in Taiwan. Sci. Total Environ. 368, 884-897. https://doi.org/10.1016/j.scitotenv.2006.03.039

Liu, S.C., Shiu, C.J. (2001). Asian Dust Storm and Their Impact on the Air Quality of Taiwan. Aerosol Air Qual. Res. 1, 1-8. https://doi.org/10.4209/aaqr.2001.06.0001

Liu, T.H., Tsai, F., Hsu, S.C., Hsu, C.W., Shiu, C.J., Chen, W.N., Tu, J.Y. (2009). Southeastward transport of Asian dust: Source, transport and its contributions to Taiwan. Atmos. Environ. 43, 458-467. https://doi.org/10.1016/j.atmosenv.2008.07.066

Liu, X., Easter, R.C., Ghan, S.J., Zaveri, R., Rasch, P., Shi, X., Lamarque, J.F., Gettelman, A., Morrison, H., Vitt, F., Conley, A., Park, S., Neale, R., Hannay, C., Ekman, A.M.L., Hess, P., Mahowald, N., Collins, W., lacono, M.J., Bretherton, C.S., ... Mitchell, D. (2012a). Toward a minimal representation of aerosols in climate models: Description and evaluation in the Community Atmosphere Model CAM5. Geosci. Model Dev. 5, 709-739. https://doi.org/10.5194/gmd-5-709-2012

Liu, X., Shi, X., Zhang, K., Jensen, E.J., Gettelman, A., Barahona, D., Nenes, A., Lawson, P. (2012b). Sensitivity studies of dust ice nuclei effect on cirrus clouds with the Community Atmosphere Model CAM5. Atmos. Chem. Phys. 12, 12061-12079. https://doi.org/10.5194/acp-12-120612012

Muhlbauer, A., Lohmann, U. (2009). Sensitivity studies of aerosol-cloud interactions in mixedphase orographic precipitation. J. Atmos. Sci. 66, 2517-2538. https://doi.org/10.1175/2009JA S3001.1 
Murray, B.J., O'sullivan, D., Atkinson, J.D., Webb, M.E. (2012). Ice nucleation by particles immersed in supercooled cloud droplets. Chem. Soc. Rev. 41, 6519-6554. https://doi.org/10.1 039/C2CS35200A

Niemand, M., Möhler, O., Vogel, B., Vogel, H., Hoose, C., Connolly, P., Klein, H., Bingemer, H., DeMott, P., Skrotzki, J., Leisner, T. (2012). A particle-surface-area-based parameterization of immersion freezing on desert dust particles. J. Atmos. Sci. 69, 3077-3092. https://doi.org/10.1 175/JAS-D-11-0249.1

Parungo, F., Li, Z., Li, X., Yang, D., Harris, J. (1994). Gobi dust storms and the Great Green Wall. Geophys. Res. Lett. 21, 999-1002. https://doi.org/10.1029/94GL00879

Perry, K.D., Cahill, T.A., Eldred, R.A., Dutcher, D.D., Gill, T.E. (1997). Long-range transport of North African dust to the eastern United States. J. Geophys. Res. 102, 11225-11238. https://doi.org/ 10.1029/97JD00260

Prenni, A.J., Petters, M.D., Kreidenweis, S.M., Heald, C.L., Martin, S.T., Artaxo, P., Garland, R.M., Wollny, A.G., Pöschl, U. (2009). Relative roles of biogenic emissions and Saharan dust as ice nuclei in the Amazon basin. Nat. Geosci. 2, 402-405. https://doi.org/10.1038/ngeo517

Provençal, S., Buchard, V., da Silva, A. M., Leduc, R., Barrette, N., Elhacham, E., Wang, S. H. (2017). Evaluation of $\mathrm{PM}_{2.5}$ surface concentration simulated by Version 1 of the NASA's MERRA Aerosol Reanalysis over Israel and Taiwan. Aerosol Air Qual. Res. 17, 253-261. https://doi.org/10.4209/ aaqr.2016.04.0145

Remoundaki, E., Bourliva, A., Kokkalis, P., Mamouri, R.E., Papayannis, A., Grigoratos, T., Samara, C., Tsezos, M. (2011). PM 10 composition during an intense Saharan dust transport event over Athens (Greece). Sci. Total Environ. 409, 4361-4372. https://doi.org/10.1016/j.scitotenv.2011. 06.026

Shahsavani, A., Naddafi, K., Jafarzade Haghighifard, N., Mesdaghinia, A., Yunesian, M., Nabizadeh, R., Arahami, M., Sowlat, M.H., Yarahmadi, M., Saki, H., Alimohamadi, M., Nazmara, S., Motevalian, S.A., Goudarzi, G. (2012). The evaluation of $\mathrm{PM}_{10}, \mathrm{PM}_{2.5}$, and $\mathrm{PM}_{1}$ concentrations during the Middle Eastern Dust (MED) events in Ahvaz, Iran, from april through september 2010. J. Arid. Environ. 77, 72-83. https://doi.org/10.1016/j.jaridenv.2011.09.007

Song, C.H., Carmichael, G.R. (2001). A three-dimensional modeling investigation of the evolution processes of dust and sea-salt particles in east Asia. J. Geophys. Res. 106, 18131-18154. https://doi.org/10.1029/2000JD900352

Tao, W.K., Chen, J.P., Li, Z., Wang, C., Zhang, C. (2012). Impact of aerosols on convective clouds and precipitation. Rev. Geophys. 50, RG2001. https://doi.org/10.1029/2011RG000369

Tegen, I., Hollrig, P., Chin, M., Fung, I., Jacob, D., Penner, J. (1997). Contribution of different aerosol species to the global aerosol extinction optical thickness: Estimates from model results. J. Geophys. Res. 102, 23895-23915. https://doi.org/10.1029/97JD01864

Thompson, G., Eidhammer, T. (2014). A study of aerosol impacts on clouds and precipitation development in a large winter cyclone. J. Atmos. Sci. 71, 3636-3658. https://doi.org/10.1175/J AS-D-13-0305.1

Tsai, F., Tu, J.Y., Hsu, S.C., Chen, W.N. (2014). Case study of the Asian dust and pollutant event in spring 2006: Source, transport, and contribution to Taiwan. Sci. Total Environ. 478, 163-174. https://doi.org/10.1016/j.scitotenv.2014.01.072

Uematsu, M., Duce, R.A., Prospero, J.M., Chen, L., Merrill, J.T., McDonald, R.L. (1983). Transport of mineral aerosol from Asia over the North Pacific Ocean. J. Geophys. Res. 88, 5343-5352. https://doi.org/10.1029/JC088iC09p05343

Uno, I., Eguchi, K., Yumimoto, K., Takemura, T., Shimizu, A., Uematsu, M., Liu, Z., Wang, Z., Hara, Y., Sugimoto, N. (2009). Asian dust transported one full circuit around the globe. Nat. Geosci. 2, 557-560. https://doi.org/10.1038/ngeo583

Wang, X., Huang, J., Ji, M., Higuchi, K. (2008). Variability of East Asia dust events and their longterm trend. Atmos. Environ. 42, 3156-3165. https://doi.org/10.1016/j.atmosenv.2007.07.046

Winker, D. (2018). CALIPSO Lidar Level 2 Vertical Feature Mask Data V4-20 [Data set]. NASA Langley Atmospheric Science Data Center DAAC. https://doi.org/10.5067/CALIOP/CALIPSO/LI D_L2_VFM-STANDARD-V4-20

Wu, C., Lin, Z., Liu, X., Li, Y., Lu, Z., Wu, M. (2018). Can climate models reproduce the decadal change of dust aerosol in East Asia? Geophys. Res. Lett. 45, 9953-9962. https://doi.org/10.10 29/2018GL079376 
Xu, X., Wang, J., Wang, Y., Henze, D.K., Zhang, L., Grell, G.A., McKeen, S.A., Wielicki, B.A. (2017). Sense size-dependent dust loading and emission from space using reflected solar and infrared spectral measurements: An observation system simulation experiment: UV-VIS-NIR-IR OSSE for Dust Emission. J. Geophys. Res. 122, 8233-8254. https://doi.org/10.1002/2017JD026677

Yu, F., Luo, G. (2009). Simulation of particle size distribution with a global aerosol model: Contribution of nucleation to aerosol and CCN number concentrations. Atmos. Chem. Phys. 9, 7691-7710. https://doi.org/10.5194/acp-9-7691-2009

Zender, C.S., Bian, H., Newman, D. (2003). Mineral Dust Entrainment and Deposition (DEAD) model: Description and 1990s dust climatology.J. Geophys. Res. 108, 4416. https://doi.org/10. 1029/2002JD002775

Zhang, X.Y., Gong, S.L., Zhao, T.L., Arimoto, R., Wang, Y.Q., Zhou, Z.J. (2003). Sources of Asian dust and role of climate change versus desertification in Asian dust emission. Geophys. Res. Lett. 30, 2272. https://doi.org/10.1029/2003GL018206

Zhang, Y., Luo, G., Yu, F. (2019). Seasonal variations and long-term trend of dust particle number concentration over the Northeastern United States. J. Geophys. Res. 124, 13140-13155. https://doi.org/10.1029/2019JD031388

Zhang, Y., Yu, F., Luo, G., Chen, J.P., Chou, C.C.K. (2020). Impact of mineral dust on summertime precipitation over the Taiwan region. J. Geophys. Res. 125, e2020JD033120. https://doi.org/1 0.1029/2020JD033120

Zimmermann, F., Weinbruch, S., Schütz, L., Hofmann, H., Ebert, M., Kandler, K., Worringen, A (2008). Ice nucleation properties of the most abundant mineral dust phases. J. Geophys. Res. 113, D00A18. https://doi.org/10.1029/2008JD009982

Zou, X.K., Zhai, P.M. (2004). Relationship between vegetation coverage and spring dust storms over northern China. J. Geophys. Res. 109, D03104. https://doi.org/10.1029/2003JD003913 